\title{
METABOLIC PROFILE TEST IN IRAN: VARIATIONS OF METABOLITES AROUND PARTURITION AT DAIRY CATTLE
}

\author{
H.A.Seifi, P. Mirshokraie, N. Farzaneh \\ Department of Clinical Sciences, School of veterinary medicine, Ferdowsi University of Mashhad, \\ P.O.Box: 1793 Mashhad 91775 Iran
}

\begin{abstract}
"Metabolic profile" or "blood profile" was defined as a set or combination of blood constituents analyzed together in one test. Metabolic Profile test (MPT) was used as a diagnostic approach in Iran in recent years. Reference values of metabolites were determined by Seifi (1996).

Calving, with the demands for initiating milk production, places high-producing cows in a critical nutrient balance and may affect profiles for 60 or more days after calving. Production level is one aspect of the periparturient flux that may reflect in the profile. Glucose and PCV are negatively correlated and total proteins; $\mathrm{Mg}$ and cholesterol are positively correlated with the post parturient rise in milk production. The aim of this study was to evaluate the variations of serum metabolites around parturition.
\end{abstract}

The investigation was conducted in two dairy farms in Mashhad city in north east of Iran. One hundred cows were bled on four occasions: 20-10 days prepartum, 3-7 days, 30 days and 56-60 days postpartum. Blood samples were drawn from Jugular vein and analyzed by computerized analyzer (RA1000 Technicon). The following metabolites and enzymes were measured on serum samples: glucose, urea nitrogen, cholesterol, albumin, total protein, calcium, inorganic phosphorus and Aspartate Aminotransferase (AST). Data were analyzed for statistical significance by analysis of variance using SPSS program for Windows. A $p$ value less than 0.05 were considered as significant.

In farm 1, prepartum variations in urea nitrogen, cholesterol, albumin, calcium, AST, PCV and total protein and in farm 2 prepartum variations in glucose, cholesterol, calcium, phosphorus, AST, PCV, and total protein were significant $(\mathrm{p}<0.05)$.

Serum glucose level decreased markedly 3-7 days postpartum and gradually increased at 30 and 5660 days postpartum. At least $92 \%$ of dairy cows suffer negative energy balance at early lactation. At this stage, the level of milk production reaches to peak earlier than dry matter intake and the result is low blood glucose. The peak of urea nitrogen concentration was found preparturition and it decreased postpartum. The concentration of serum cholesterol was lower at 10-20 days prepartum and after calving gradually increased. The peak of serum calcium levels was found 10-20 days before calving and it was markedly decreased after parturition. Serum total protein and PCV values were lowest at preparturition sampling. AST activity levels were lower at first sampling and reached highest after parturition. AST relates to metabolism, and it seems increased activity of the enzyme in high producing dairy cows is due to increased of body metabolic and hepatic activities .

\section{Reference}

Ingraham, R.H. (1988) Metabolic profile testing. Vet. Clin. North Am.: Food Anim.Prac.4, 391-411.

Seifi, H.A. (1996) Metabolic Profile Status of Dairy Herds In Tehran Province. DVSc. Thesis. University of Tehran 